\title{
THEORETICAL AND LEGAL BASIS OF YOUNG PEOPLE'S MILITARY CAREER IN THE FIELD OF NATIONAL DEFENCE
}

\author{
*Sandra Kreija-Gaikste, Irena Katane \\ Latvia University of Life Sciences and Technologies, Latvia \\ *Corresponding author's email: sandra.kreija_gaikste@inbox.lv
}

\begin{abstract}
Research in many countries across the world, including Latvia, shows that youth participation in national defence is a topical issue. So far, scholarly research focusing on the promotion of youth participation in national defence and the provision of career support at school age and after finishing school is scarce. Therefore, the aim of the research was to establish the basis for young people's military career in national defence. Research results show that there is both theoretical and legal basis for young people to start a military career, already during school years. Based on the broad meaning of the concepts career and career development, young people's self-development, self-management and self-actualisation in various fields of human activity over one's lifetime emerge as topical issues. Such activities of various kinds may follow one another in succession or take place simultaneously, in parallel, in accordance with dual career theories. The beginning and development of young people's military career in Latvia can occur in the context of various activities already present and available in the near future: 1) participation in the Latvian Youth Guard as a type of non-formal education, 2) acquisition of National defence training at school in the context of formal education, 3) upon reaching legal age, voluntarily joining the Latvian National Guard, which is a component of the National Armed Forces of the Republic of Latvia.

Key words: formal and non-formal education, the Latvian Youth Guard, the Latvian National Guard, national defence, young people's military career.
\end{abstract}

\section{Introduction}

Several countries in the world have developed their own national defence concepts, which emphasise and highlight the role of youth participation in national defence, for example, France (Gougeon, 2017), Estonia (Estonian Ministry of Defence, 2011), the Russian Federation (Russian Federation's National ..., 2015), and others.

Scholars in many countries have published research on youth participation in national defence and related issues. For example, research carried out in the USA (Spoehr \& Hand, 2018) shows that the armed forces may face issues concerning employment in the future (namely, the ability to recruit professional staff). There are several causes of this problem, for instance, limitations laid down in various legislative documents stipulating that only $29 \%$ of young people may be involved in professional national defence, among others. This poses a threat to continuity and generational renewal in the armed forces. Young people's motivation is another important factor to take into account.

Researchers outside Latvia have concluded in their studies that, in order to raise youth participation in national defence, it is necessary to raise awareness of the importance of civic education and provide a well thought-out civic education curriculum (Kalagbor \& Harry, 2018).

Several documents regarding national defence have also been prepared in the Republic of Latvia, including the National Security Concept (LR Ministru kabinets, 2019), the Cyber Security Strategy of Latvia for 2019-2022 (LR Aizsardzības ministrija, 2019a), and $\mathrm{On}$ the introduction of national defence as a subject and the development of Youth Guard in 20192027 (LR Aizsardzības ministrija, 2019b). These documents emphasise that 1) the aim of projects implemented as part of school and youth policy should be: the promotion of public engagement among young people; the exploration of historic events at parish, municipal, and national level; involvement in decision making so as to develop local patriotism and sense of belonging to the state; 2) it is necessary to educate young school-age people by building media competence and thus strengthening the psychological resilience of the younger members of society against threats and malicious actions in the information space in the long term; 3) National defence training should be introduced as a school subject to promote youth participation in national defence; the Youth Guard should continue its work, as its members could become the next generation to join the National Guard and enlist for professional service in the National Armed Forces of the Republic of Latvia.

Taking these considerations into account, it can be concluded that promoting youth preparedness for various types of participation in national defence is a request made by the state addressing the formal and non-formal education system in Latvia, and it has legal justification. At the same time, research conducted in Latvia (Vaine et al., 2006) shows that, unfortunately, grade 8 students do not consider military career to be among the top 10 most promising fields of work. The opinions and attitudes of grade 11 students, when asked about the most promising fields of work, reflect a similar situation. Providing young people with career guidance in the military field can therefore be considered a vital issue to ensure that young people 
can coordinate the three groups of factors determining their career choice (Aron, 2015; Katane et al., 2017): 1) personal interests, needs, future goals and plans (what I want), 2) knowledge, skills, competences manifested as different abilities; experience (what I can), 3) the needs and demands of society, national priorities (what is needed).

So far, scholarly research focusing on the promotion of youth participation in national defence and the provision of career support at school age and after finishing school is scarce. Therefore, the aim of the research was to establish a basis for young people's military career in national defence.

\section{Materials and Methods}

In 2019, research on the promotion of young people's career in the field ofdefence was launched at the Latvia University of Life Sciences and Technologies. To conduct empirical research, a theoretical and legal basis is required. For this reason, the present paper introduces the results of theoretical research carried out by the authors, providing a rationale for young people's career in the military, beginning from school years and continuing until later, after finishing school. The following research methods were used: 1) review, analysis, and evaluation of scientific literature and various documents; 2) reflection on experience.

\section{Results and Discussion}

The theoretical basis of young people's career

Nowadays, in the $21^{\text {st }}$ century, the concept of career is interpreted both in a narrow and broad sense. Multiple studies carried out in Latvia (Bloka, 2009; Gaile, 2019; Garleja \& Kangro, 2015; Lemešonoka, 2014; Libkovska, 2011; Pudule, 2013) affirm both of these interpretations. Research shows that the reason for such variety of interpretations is the historical development of the concept of career and a gradual paradigm shift.

At first, career as a concept was generally associated with the chosen profession, a person's job and the employment process in a more narrow sense (namely, to what extent the choice of profession and professional development and growth can be considered successful), as well as work experience accumulated over time, and/or an individual's professional experience and the sequence of tasks to be completed in the respective position (Arnold, 1997; Arthur, Hall, \& Lawrence, 1989; Arthur, Inkson, \& Pringle, 1999; Lemešonoka, 2014).

Similarly, psychologist D. Super associated the notion career with professional development in his early research (Super, 1957). Based on his longterm research, together with fellow researchers and followers (D. Super, Savickas, \& C. Super, 1996), he later established an important idea that career is a life- long process that develops person's skills, abilities, and interests; the career development process accumulates new knowledge, establishes new characteristic features and attitudes, such as responsibility towards one's work, whose foundation, for a large part, lies in a person's system of values. These scientific findings significantly broadened the scope of the meaning of careers' idea.

Like D. Super and his followers, other scientists also came to the conclusion that career encompasses all-round personal development in main human activities, including social activities, in the context of achievement and successful self-actualisation over one's lifetime, deliberately satisfying one's personal needs, where as career development means the professional development of the person as a specialist and their character due to the interplay of these factors (Osipow \& Fitzgerald, 1996).

The broad meaning of career as a notion is largely explained by etymology. The word career stems from the Latin word carrus, meaning cart, carriage. In Italian, carriera has the connotations of a run, the course of a person's life, one's field of work. In French, the word carrière can be defined as taking the lead in a particular field of activity, reaching popularity and fame (Хачатурян, 1999).

Several scientists established career theories in the $20^{\text {th }}$ century, contributing to the multidimensional development of the concept. Career choice and development was studied and substantiated based on various perspectives with respect to 1) heredity and social learning (Krumboltz, 1994); 2) an individual's ability to achieve one's full potential in a varied environment, ensuring balance between one's interests, needs and goals and the interests, needs, development and functioning goals of the social environment (social group, for example, team at work, organisation, society at large), which ensures successful career development (Holland, 1985).

Nowadays, based on the views of career management theorists, scientists generally interpret the notion career in the broader sense, namely, as individual and professional development across a person's lifetime (Patton \& McMahon, 2014).

In her research, I. Lemeshonoka (Lemešonoka, 2014) underlines a comprehensive approach to the foundation, development, and study of one's career, which may serve as a conceptual basis for interpreting the notion career in its broader sense.

The semantic widening of the concept career can be also explained by the fact that historically career was studied within the context and from the perspective of different fields: psychology, sociology, political science, economics and management, and others.

For example, research carried out by G. Pudule (Pudule, 2013) explains the notion career from this 
multidimensional, multidisciplinary perspective: 1) in economics, career is analysed as a reaction to the impact of market economy by analysing and studying response to short-term employment opportunities and accumulation of human capital in the longterm; 2) in management science, career is related to the development of human resource management; 3) in political science, career is analysed as the realisation of the interests of the European Union, focusing on an individual's need for power, welfare, prestige, and independence as an important manifestation of the European Union's interests within an institutional and political reality; 4) in sociology, career is analysed as the fulfilment of social roles, which overlaps with social psychology ideas, the difference being that sociology emphasises the mutual benefit gained by an individual and the society; career is also analysed in the context of social mobility. By far, the greatest influence on the development of career theories and career as a notion comes from research in psychology, where career is studied as 1) profession, in line with the view in traditional psychology that adult personality is characterised by stability; 2) self-actualisation, which represents the humanistic perspective and views career as individual growth having beneficial effect on the organisation where the individual is employed, as well as society as a whole; 3 ) part of an individual's life, supporting the idea that career is a multi-stage cyclical process which spans an entire lifetime and, like character development, is largely predictable, as it conforms with a human being's biological and social nature, that is, established regularities; 4) an individual's response to societal roles to be learned, including roles associated with professional activity; therefore, conditions specific to each profession should be studied, as they have a psychological impact on an individual's career development.

Several career development theories show career as a life-long multi-stage cyclical process. For example, S. Axelrad, E. Ginzberg, S.W. Ginsburg and J. Herma (Ginzberg et al., 1951) provide a description of career development stages, beginning in childhood and young age, for instance: 1) stage one (until age 10-12) is characterised as fantasy through play; there are aspirations for the future, but these wishes are detached from reality; 2) stage two (12-16 years) is the stage of experimentation and temporary work, when interests, abilities and skills are determined; this is the age when one becomes aware of one's talents, likes and dislikes; 3 ) stage three (above age 17 ) is the stage when a realistic decision is made. This stage is divided in two levels. The first level involves making a decision on one's profession, based on one's experience - education, qualification, previous experimentation. Career development goals are defined and elaborated.
Notably, this framework can be used to exemplify career development theories, but it is more relevant to $20^{\text {th }}$ century generations and only loosely applicable to the $21^{\text {st }}$ century generations. The authors' experience shows that nowadays actual career development may start much sooner. Young school-age people may already be top-class athletes or winners of international music and dance competitions. Children and young people may appear in fashion shows, not unlike professional models. The Latvian Youth Guard is also such an example, where children and young people acquire real knowledge, skills, and competence in the military and have an opportunity to apply theoretical knowledge in practice.

Nowadays, career is explained and studied from various aspects, including the following (Bloka, 2009; Gaile, 2019; Garleja \& Kangro, 2015): a person's professional experience during their lifetime; a person's employability; an experience of social interaction, which develops one's personal and social identity; leading a meaningful life, manifesting the self-evaluation of one's character competence, transforming one's competence capacity into intellectual capital; a self-regulation process where competence creates an added value in the form of social acceptance in the context of employing one's abilities; the effective use of a human's resources and inner potential in achieving life goals; dedicated efforts to build and employ one's competence over the entire lifetime; continual learning and development process; a person's social and professional advancement over the entire life.

Therefore, according to career theories of the $21^{\text {st }}$ century, career is understood not only as professional growth, but also as logical development of one's character and the sequential change or mutual complementation of one's activities over the lifetime. Career is the dedicated, meaningful course of life of an individual; it is the sum of all roles, leisure activities, studies and work over the life of an individual.

Experience shows that nowadays one of the goals of education is to ensure career support to young people, including the provision of professional career pedagogues and career counsellors within the school education environment so as to promote the development of young people's careers, including professional self-determination.

Based on the broad meaning of the notion career in various career theories, as well as personal experience, the authors of the paper conclude that it is crucial for specialists involved in youth education to realise that it is not sufficient to view young people's career only from a future perspective, when appropriate education and professional skills will already have been acquired. It should also be examined from the viewpoint of the present, because youth career is established 
and developed already at school: within formal and nonformal education, professional (such as arts, music, dance, sports, and other) education, as well as general comprehensive secondary education process. Professional education programmes are implemented simultaneously with the general basic education programme (LR Saeima, 1999). Experience shows that various types of programmes may be offered by the same education institution (for instance, general education institution (school) with classes providing additional vocational direction education, such as classes dedicated to music or sports education), or by different education institutions attended by children or youth (for example, general education elementary school and another school dedicated to music, the arts, or sports). General secondary education provides the following study directions for young people (LR Saeima, 1999):

- The general education direction, which is specified by the group of educational programmes without particularly emphasised subjects.

- The humanities and social direction specified by the group of educational programmes with particularly emphasised humanities subjects and social science subjects.

- The mathematics, natural sciences and technology direction determined by the group of educational programmes with particularly emphasised mathematics, natural sciences and technology subjects.

- The vocational direction determined by the group of educational programmes with a particularly emphasised vocational orientation (for example, the arts, music, business, sports, and others).

The diverse education acquired by young people already at school and later can be considered a significant part of their career, bringing new knowledge, skills, and competence to serve as the basis for their life as a whole, including professional development and activity.

Starting and developing of young people's military career in national defence area is already possible and will be so in the future: in formal education by studying the subject National defence training, and in nonformal education by participating in the Youth Guard, which offers various levels of education programmes. Such types of military education for young schoolage people is a key component of career; for many young people, up on finishing school, the general experience acquired, as well as knowledge, skills, and competence in the field of national defence may serve as the basis for further development of military career in the Latvian National Guard or the National Armed Forces of the Republic of Latvia.
The historical and legal basis for the development of young people's military career in Latvia and future outlook for national defence

Considering the broad meaning of the notions career and career development, which imply that career encompasses the entirety of a person's life, including self-actualisation and personal and professional development by learning various social roles, youth participation in the Youth Guard as interest-related education or the National Guard as voluntary activity in the military context should also be considered a significant part of one's career if it becomes an important part of the person's life.

The Youth Law of the Republic of Latvia (LR Saeima, 2008) underlines that the purpose of the Law is to improve the quality of life of young people (persons from 13 to 25 years of age) by promoting their initiatives, work ethic and patriotism, participation in decision-making and social life. Therefore, support for youth is important in all activities they undertake in their life. In the context of career in its broader sense, the Youth Law highlights the vital role of support in young people's career development.

In addition to introducing new, competence-based curriculum, it is also necessary to review and bring into focus how children and young people develop and strengthen their sense of statehood and belonging to Latvia, learn to take responsibility for themselves, their family, community and the state, develop intellectual as well as physical ability, all during the process of acquiring education. In order to develop a society that is cohesive, resilient to external influence and able to mobilise in critical circumstances, each member of society needs to be aware of their role, duties and rights in emergency situations, they also need to be prepared to make decisions and take action in a very changeable environment. These competences are to be acquired and developed mainly in the family and at school, starting from early childhood, and also within extracurricular activities, including the Youth Guard, the largest children and youth movement in the military field in Latvia (LR Aizsardzības ministrija, 2019b). The goal of introducing the subject national defence in Latvian schools, namely, in formal education, and the Youth Guard, or non-formal education, is: to develop the skills and abilities necessary for life and national defence and promote civic consciousness and patriotism. Therefore, introducing National defence training as a compulsory study subject in formal education and studying the non-formal education curriculum provided by the Youth Guard, promotes young people's military career development by engaging them in various activities and acquiring the knowledge, skills and competence necessary for national defence. 
Notably, since the 2018/2019 school year, the subject National defence training is already provided in several schools in Latvia which have voluntarily joined the approbation of the new curriculum and study process. Starting from the 2024/2025 school year, National defence training will be a mandatory subject in all schools in Latvia. It will be studied in grade 10 and 11 in general education secondary schools and in year 2 and 3 in vocational education institutions. According to forecasts from the Ministry of Defence of the Republic of Latvia, approximately 34000 young people will study the subject in the first year when it becomes mandatory. The subject provides for individual approach with consideration of the worldview of students and their parents, including their religion and its respective values, beliefs, attitudes, actions, and behavioural norms. The curriculum will be taught at school and in camps offering practical exercises, therefore classroom attendance atnational defence will be mandatory. However, schoolchildren engaged in distance and extramural education will have the opportunity to acquire new knowledge by only studying theoretical blocks, or modules, of the curriculum (Kuzmina, 2020).

Further developments are also planned for nonformal education in the Youth Guard, offering new Youth Guard education programmes. For example, there are plans to introduce Cyber Youth Guard classes in addition to level 2 Youth Guard interest-based education programme (for grade 7 and 8 students). Afterwards, these students can choose to enrol in a relevant vocational secondary education programme (for example, the Saldus Technical School already provides a programme for aspiring cyber security specialists) or a higher education programme in information technology with specialisation in cyber security (LR Aizsardzības ministrija, 2019b). As a result, new opportunities for young people's career development will become available.

The Youth Guard provides voluntary interestrelated education (considered by the authors as a type of non-formal education) organised by the Ministry of Defence of the Republic of Latvia, which helps young people build civic consciousness andincrease understanding of democratic society and national defence. The aim of the Youth Guard is to educate the youth about national defence; develop patriotism, civic consciousness, companionship, courage, physical ability and discipline; promote the National Armed Forces and military service among young people, as a result expanding recruitment opportunities of motivated professional soldiers (Ciganovs, 2019). The Military Service Law of the Republic of Latvia (LR Saeima, 2002) provides that: 1) children and youth from 10 up to 21 years of age may operate in the voluntary movement Youth Guard, whose purpose is educating of youth in the field of national defence and the promotion of civic consciousness and patriotism; 2) the work of the Youth Guard, and also educating of youth in the field of national defence according to the interest-based education programme for youth guards is organised and implemented by the Cadet Force Centre or its authorised persons, 3) a model interest-based education programme for youth guards is approved by the Minister of Defence; 4) the Cadet Force Centre has the right to purchase weapons and ammunition for the purpose of carrying out the specified tasks; the procedures for storing and using them are stipulated by the Minister of Defence; 5) the uniform of a youth guard and an employee of the Cadet Force Centre and the identifying insignia of the Youth Guard, as well as the procedures for its use are determined by the Minister of Defence; the uniform of a youth guard and an employee of the Cadet Force Centre may be made of the fabric whose pattern is identical to that of the uniform of a soldier; 6) when a child joins the Youth Guard movement, the Cadet Force Centre enters into a contract on the participation of the child in the movement Youth Guard with their legal representative, but, if the young person has attained 18 years of age, the contract is concluded with the participant; 7) youth guards have the right to receive paid health care; the types, amount of paid health care services, conditions for receipt, and the procedures for payment are determined by the Cabinet of Ministers; 8) after reaching 18 years of age, a youth guard who complies with the requirements laid down in the Law and the conditions specified for the service into reserve may voluntarily complete a special interest-based education programme course for youth guards approved by the Minister of Defence; after successfully passing a final examination of this course, a youth guard takes an oath, is included in the National Armed Forces' reserve and awarded the rank of a private; if a youth guard has enlisted in professional service, they shall complete a basic training course of a soldier in accordance with the procedures stipulated by the Minister of Defence; 9) a reserve soldier may be removed from the military service record for various reasons, such as health conditions; one possible reason is voluntary joining the National Guard.

Career opportunities for young people in Latvia in the National Guard and Youth Guard emerged in the early 1990s. On 21 August 1991, immediately following the de facto restoration of independence of Latvia, the National Guard of the Republic of Latvia was established. Ever since its first battalions were formed, the National Guards who attended military training brought their children with them and, on their own initiative, engaged them in various National Guard activities. Children and youth groups spontaneously appeared along with the National Guard battalions, 
and members of these groups were named the youth guards. During that time, Scout and 4-H organisations were restored on the initiative of separate individuals, and their programmes included patriotic and physical education for young people as well as productive free time activities, but not basic military skills. These skills were not provided by general education schools, either, and at that time there was no organisation that would educate school-age youth in the field of national defence. The Management of the National Guard took the coordination efforts and made a decision to merge and structure most of the children and youth groups established along with the respective National Guard battalions. On 25 November 1992, the Interim Regulations on the Youth Guard organisation of the Republic of Latvia were adopted at the National Guard Headquarters, and these regulations were approved by the Ministry of Education, Science and Culture of the Republic of Latvia on 30 November. The Regulations defined the three main objectives of the Youth Guard: to manage and organise the participation of young people in the Youth Guard; to provide the youth with the knowledge and skills necessary to prepare for military service; and to provide patriotic education for young people. The name Youth Guard, which until then had been used unofficially, also appeared in these Regulations for the first time (Ciganovs, 2019).

Military career options for young people are also laid down in The National Guard of the Republic of Latvia Law (LR Saeima, 2010). The purpose of this Law is to involve the citizens of Latvia in State defence. The Law also applies to young people who have reached legal age. It provides various support mechanisms to ensure motivated and voluntary participation in the National Guard within a cohesive national defence system. As the Law provides that the National Guard is a component of the National Armed Forces, in order to serve in the National Guard, the National Guards, including young people of legal age, have to give an oath and engage in career selfmanagement to be able to combine studies in an education institution (for example, university) or work in a civil profession with military career duties in accordance with the Law. This problem provides the authors of this paper with opportunities for further study so as to provide theoretical basis for young people serving in the National Guard as a dual career.

\section{Conclusions}

1. Nowadays, the importance of youth participation in national defence is a topical issue in Latvia and globally, as it can contribute to national independence and social sustainability in the territory of one's country. Increasingly more attention is paid to the importance of young people's military career development, starting already in school years and afterwards.

2. According to career theories of the $21^{\text {st }}$ century, career is explained not only as professional growth, but also as logical character development and the sequential change or mutual complementation of one's activities across a person's lifetime. Career is the dedicated, meaningful course of life of an individual; it is the sum of all roles, leisure activities, studies and work over the life of an individual. Therefore, $20^{\text {th }}$ century and especially $21^{\text {st }}$ century career theories may serve as theoretical basis for young people's military career.

3. Based on the broad meaning of the concepts career and career development, young people's self-development, self-management and selfactualisation in various fields of human activity over one's lifetime emerge as topical issues. Such activities of various kinds may follow one another in succession or take place simultaneously, in parallel, in accordance with dual career theories.

4. The beginning and development of young people's military career in Latvia can occur in the context of various activities with legal basis: 1) participation in the Latvian Youth Guard as a type of non-formal education, 2) taking national defence classes at school in the context of formal education, 3) upon reaching legal age, voluntarily joining the Latvian National Guard, which is a component of the National Armed Forces of the Republic of Latvia.

5. In the near future, young school-age people will face new opportunities in military career development. The introduction of national defence as a subject in all schools in Latvia will affect the curriculum of the Youth Guard, including the Cyber Youth Guard, as well as school curriculum within the context of formal education.

6. To conclude, there is both theoretical and legal basis for young people in Latvia to start and develop a military career already during school years.

\section{References}

Arnold, J. (1997). Managing Careers into the $21^{\text {st }}$ Century. London: Paul Chapman.

Aron, I.S. (2017). Agency in Professional Self-Determination of Adolescents with Special Social Situations of Development. Cultural-Historical Psychology, 13(4), 64-72. DOI: 10.17759/chp.2017130407.

Arthur, M.B., Hall, D.T., \& Lawrence, B.S. (1989). Generating new directions in career theory. Cambridge: Cambridge University Press.

Arthur, M.B., Inkson, K., \& Pringle, J.K. (1999). The new careers: Individual action and economic change. Thousand Oaks, CA: Sage. 
Arthur, M.B., Khapova, S.N., \& Wilderom, C.P.M. (2005). Career success in a boundaryless career world. Journal of Organizational Behavior, 26(2), 17-202. DOI: 10.1002/job.290.

Bloka, R. (Red.). (2009). Karjeras izglītība skolā. Rīga: VIAA. (Career Education at School). (in Latvian).

Ciganovs, J. (2019). Jaunsardze (The Latvian Youth Guard). Nacionālā enciklopēdija. Retrieved February 18, 2020, from https://enciklopedija.lv/skirklis/31494-jaunsardze. (in Latvian).

Gaile, A. (2019). Indivīda karjeras rīcību un individuālo vērtību mijiedarbība un ietekme uz subjektīvi veiksmïgu karjeru (Interaction of personal career behaviours and values of an individual and effect thereof on subjective career success). Promocijas darbs. Rīga: RISEBA. (in Latvian).

Garleja, R., \& Kangro, I. (2015). Kompetence - karjeras iespēju garants. (Competence - the guarantor of career opportunities). In Proceedings of the International Scientific Conference Society. Integration. Education (pp. 133-144). Rezekne: RA. (in Latvian).

Ginzberg, E., Ginsburg, S.W., Axelrad, S., \& Herma, J. (1951). Occupational choice: An approach to a general theory. New York - London: Columbia University Press; Oxford University Press.

Gougeon, C.F.-M. (Ed.). (2017). Defence and National Security Strategic Review. Paris: Ministry of the Armed Forces (Secretariat of the Committee).

Holland, J.L. (1985). Making vocational choices: A theory of vocational personalities and work environments. Englewood Cliffs, NJ: Prentice Hall.

Kalagbor, S.B., \& Harry, D.M. (2018). Youth Empowerment and National Security in Nigeria: Issues and Prospects. Global Journal of Political Science and Administration, 6(3), 1-14.

Katane, I., Katans, E., Korna, E., \& Kristovska, I. (2017). Students’ professional direction towards engineering professions at comprehensive secondary schools in the context of self-determination. In A Aboltins (Ed.), Proceedings of the $16^{\text {th }}$ International Scientific Conference Engineering for Rural Development, Vol. 16, (pp. 811-818). Jelgava: LLU TF. DOI: 10.22616/ERDev2017.16.N165.

Krumboltz, J.D. (1994). Improving Career Development Theory from a Social Learning Perspective. In M.L. Savickas, R.L. Lent (Eds.), Convergence in Career Development Theories (pp. 9-31). Palo Alto, CA: CPP Books.

Kuzmina, I. (2020). Valsts aizsardzību apgūs gan skolās, gan nometnēs (National defence to be studied in schools as well as camps). Ziņu portāls Latvijai. Retrieved January 27, 2020, from https://www.la.lv/ valsts-aizsardzibu-apgus-gan-skolas-gan-nometnes?fbclid=IwAR0KRmc3v1Pkp0wFXmwFQk-mYjaUK 96Dla5zHylXjOkIL1KAWAiJP8cJphk. (in Latvian).

Lemešonoka, I. (2014). Professional Orientation and Career Education for Students. In Proceeding of the International Scientifical Conference Society. Integration. Education, Vol. 1, (pp. 448-457). Rezekne: RTA.

Libkovska, U. (2011). Skolēnu profesionālo interešu pilnveides vadība karjeras izglītībā Latvijā (Management of professional interests improvement of pupils in career education in Latvia). Promocijas darbs. Rīga: LU. (in Latvian).

LR Aizsardzības ministrija. (2019a). Latvijas kiberdrošības stratēgija 2019.-2022. gadam (The Cyber Security Strategy of Latvia for 2019-2022). Informatīvais ziņojums. Rīga: LR Aizsadzības ministrija. (in Latvian).

LR Aizsardzības ministrija. (2019b). Par valsts aizsardzības mācības ieviešanu un Jaunsardzes attīstību 2019.2027. gadā (On the introduction of national defence as a subject and the development of the Youth Guard in 2019-2027). Informativvais ziņojums. Rīga: LR Aizsardzības ministrija. (in Latvian).

LR Ministru kabinets. (2019). Nacionālās drošības koncepcija. (National Security Concept). Latvijas Vēstnesis, 197. Retrieved March 6, 2020, from https://ikumi.lv/ta/id/309647-par-nacionalas-drosibas-koncepcijasapstiprinasanu. (in Latvian).

Estonian Ministry of Defence. (2011). National Defence Strategy of Estonia. Tallin: Estonian Ministry of Defence.

LR Saeima. (2008). Jaunatnes likums (The Youth Law). Latvijas Vēstnesis, 82 (28.05.2008). Retrieved December 12, 2019, from https://likumi.lv/ta/id/175920-jaunatnes-likums. (in Latvian).

LR Saeima. (2010). Latvijas Republikas Zemessardzes likums (The National Guard of the Republic of Latvia Law). Latvijas Vēstnesis, 82. Retrieved February 18, 2020, from https://likumi.lv/ta/id/210634-latvijasrepublikas-zemessardzes-likums (in Latvian).

LR Saeima. (2002). Militārā dienesta likums (The Military Service Law). Latvijas Vēstnesis, 91. Retrieved February 18, 2020, from https://likumi.lv/doc.php?id=63405. (in Latvian).

LR Saeima. (1999). Vispārējās izglītības likums (The General Education Law). Latvijas Vēstnesis, 213/215. Retrieved February 18, 2020, from https://ikumi.lv/doc.php?id=20243. (in Latvian).

Osipow, S.H., \& Fitzerald, L.F. (1996). Theories of career development. Boston: Allyn and Bacon. 
Patton, W., \& McMahon, M. (2014). Career Development and Systems Theory. Connecting theory and Practice. Rotterdam: Sense Publishers. DOI: 10.1007/978-94-6209-635-6.

Pudule, G. (2013). Karjeras izglītības vadības pilnveide vispārizglītojošās skolās Latvijā (Improving the management of career education at the comprehensive schools of Latvia). Promocijas darbs. Riga: LU. (in Latvian).

Russian Federation's National Security Strategy. (2015). Moscow: the Kremlin.

Spoehr, Th., \& Handy, B. (2018). The Looming National Security Crisis: Young Americans Unable to Serve in the Military: Report. Washington: The Heritage Foundation. Retrieved March 6, 2020, from http://report. heritage.org/bg3282.

Super, D. (1957). The psychology of careers. New York: Harper \& Brothers.

Super, D., Savickas, M., \& Super, C. (1996). The life-span, life-space approach to careers. In D. Brown \& L. Brooks (Eds.), Career choice and development: Applying contemporary theories to practice (pp.121k178). San Francisco: Jossey-Bass.

Vaine, I., Kalēja, N., Čodere, A., \& Trupavniece, A. (2006). Pētījums par 8. un 11. klašu profesionālajiem nodomiem un priekšstatiem par profesijam (Study on the professional aspirations and perception of professions in grade 8 and 11 students). Rīga: Profesionālās karjeras izvēles valsts aǵentūra. (in Latvian).

Хачатурян, Д.К. (Ред.). (1999). Словарь иностранных слов (Dictionary of Foreign Words). Москва: Омега. (in Russian). 